\title{
Activation of monocytes, T-lymphocytes and plasma inflammatory markers in angina patients
}

\author{
Won-Ha Lee ${ }^{1}$, Yoon Lee ${ }^{2}$, Jong-Ran Kim', \\ Jin-A Chu' ${ }^{2}$, Sung-Youn Lee ${ }^{2}$, Jin-Ok Jung ${ }^{2}$, \\ Joon-Soo Kim², Seonwoo Kim ${ }^{1}$, Jung-Don \\ $\mathrm{Seo}^{2}$, Sung S. Rhee ${ }^{3}$ and Jeong-Euy Park ${ }^{1,2,4}$ \\ ${ }^{1}$ Clinical Research Center, ${ }^{3}$ Molecular Medical Research Center \\ Samsung Biomedical Research Institute, Seoul 135-230, Korea \\ ${ }^{2}$ Cardiology Division, Samsung Medical Center, College of \\ Medicine, Sung Kyun Kwan University, Seoul 135-230, Korea \\ ${ }^{4}$ Corresponding author: Tel, 82-2-3410-3416; Fax, 82-2-3410-3849; \\ E-mail, jepark@smc.samsung.co.kr
}

\section{Accepted 10 August 1999}

Abbreviations: IL, Interleukin; TF, tissue factor; MCP-1, monocyte chemoattractant protein-1; TNF- $\alpha$, tumor necrosis factor- $\alpha$; TGF$\beta 1$, transforming growth factor- $\beta 1$; CRP, C-reactive protein; sICAM1 , soluble intercellular adhesion molecule-1; VLA-1, very late activating antigen-1; G(M)-CSF, granulocyte(macrophage)-colony stimulating factor; PBS, phosphate buffered saline; LPS, lipopolysaccharide; LDL, low-density lipoprotein; CAD, coronary artery disease; UA, unstable angina; $S A$, stable angina.

\begin{abstract}
Inflammation and activation of immune cells have important roles in the pathogenesis of atherosclerosis. We analyzed the plasma levels of inflammatory markers and the degree of activation of peripheral blood monocytes and T-lymphocytes isolated from 12 unstable angina, 12 stable angina, and 12 normal subjects. In $20 \%$ $33 \%$ of patients, monocytes expressed high basal levels of IL-8, tissue factor, IL-1 $\beta$, and monocyte chemoattractant protein-1 mRNA. Furthermore, basal mRNA levels of these cytokines showed strong correlation with each other ( $p<0.01$ in all combination) but not with tumor necrosis factor- $\alpha$ or transforming growth factor- $\beta 1$. Plasma level of C-reactive protein was highest in the unstable angina patients $(1.63 \pm 0.70 \mathrm{mg} / \mathrm{l})$ and lowest in the control subjects $(0.22 \pm 0.08 \mathrm{mg} / \mathrm{l})(P=0.03)$. We also observed a high correlation between $\mathrm{C}$-reactive protein level and the occurrence of minor and major coronary events during 6 months of follow-up. Activation status of T-cells, assessed by the percentage of HLA-DR positive cells, was highest in the unstable angina patients $(26.8 \pm$
\end{abstract}

$1.4 \%)$ compared with that in the control $(14.7 \pm 1.2 \%)$ $(P=0.0053)$. Our data represent the first case showing that the circulating monocytes in angina patients are activated to a state express numerous proatherogenic cytokines. These results may help to diagnose angina patients according to the inflammatory markers and evaluate the prognosis of the disease.

Keywords: angina, monocyte, T-lymphocytes, inflammation, C-reactive protein

\section{Introduction}

Increasing evidences suggest that inflammatory changes and activation of immune cells are involved in the acute phase of coronary artery diseases (Azar and Waters, 1996). The plasma level of C-reactive protein (CRP), a marker of acute inflammation, was reported to be a predictor of coronary events in stable or unstable angina (Haverkate et al., 1997). The plasma levels of soluble intercellular adhesion molecule-1 (sICAM-1) were also shown to have a significant association with the risk of future myocardial infarction (Ridker et al., 1998).

Activation of T-lymphocytes was also observed in atherosclerotic plaque. Hansson et al. (Hansson et al., 1989) demonstrated the presence of T-cells expressing the activation antigen-1 (VLA-1) and HLA-DR. Both are synthesized only in the activated $T$ cells. In unstable angina patients, activation of T-cells was also detected in circulation. The activated CD4+ and CD8+ circulating T-lymphocytes were found to express HLA-DR (Neri Serneri et al., 1997).

Cytokines are known to be involved in the progression of coronary atherosclerosis by promoting inflammation, intravascular coagulation and cell adhesion, free-radical generation, and endothelial injury (Arai et al., 1990; De Meyer and Herman, 1997; Ikeda et al., 1998; Meydani and Dinarello, 1993; Schleef et al., 1988). Also a variety of cytokines are induced in atherosclerotic lesions (Ross, 1993). These include tumor necrosis factor (TNF)- $\alpha$ (Barath et al., 1990), Interleukin(IL)-1 $\beta$ (Hiscott et al., 1993), IL-6 (Ross, 1993), IL-8 (Terkeltaub et al., 1994), the granulocyte/macrophage-colony stimulating factors (G-CSF, M-CSF, and GM-CSF) (Clinton et al., 1992; Rosenfeld et al., 1992), monocyte chemoattractant protein-1 (MCP-1) (Cushing et al., 1990; Yla-Herttuala et al., 1991), tissue factor (TF) (Brand et al., 1991; 
Drake et al., 1991; Wilcox et al., 1989), and transforming growth factor (TGF)- $\beta 1$ (Bahadori et al., 1995; Nikol et al., 1992; Wang et al., 1997).

Monocytes play a major role in the pathogenesis of atherosclerosis in that it is one of the major sources of these cytokines. The activation status of circulating monocytes with respect to the expression of proatherogenic cytokines has not been tested yet. To investigate the degree of activation of monocytes in angina patients, we measured the mRNA levels of cytokines including TNF- $\alpha$, IL-1 $1 \beta$, IL-8, MCP-1, TF, and TGF- $\beta 1$ in circulating monocytes isolated from normal and angina patients. We also tested the level of plasma inflammatory markers and cytokines, and the activation status of circulating T-lymphocytes by flow cytometric analysis of the percentage of HLA-DR positive cells.

\section{Materials and Methods}

\section{Selection of Patients}

We selected 12 normal subjects, 12 unstable angina patients, and 12 stable angina patients (mean age \pm SD: $58.3 \pm 10.6$, male to female ratio: 3 to 1 ). For normal subjects, we recruited age and sex-matched healthy volunteers from our hospital staff. The normal subjects had no risk factors for cardiovascular disease and were not taking any medication. All patients had angiographically proven coronary artery disease. Stable angina was defined as the presence of effort angina with stable pattern over the previous 3 months with angiographically documented significant coronary artery disease. Unstable angina was defined as either angina pain of a recent onset (within 6 weeks) brought on by minimal exertion of more severe, prolonged, or more frequent anginal attack superimposed on the chronic effort angina. The blood samples were taken at the cardiac catheterization laboratory before the coronary angiography. The sampling time was usually several days after the patient was admitted. The patients had been given anti-anginal medications and intravenous heparin and nitroglycerin drop in cases of unstable angina. An informed consent from each patient was obtained before the collection of blood.

\section{Measurement of plasma levels of CRP and cytokines} Plasma prepared from heparinized blood was stored in a $-70^{\circ} \mathrm{C}$ freezer in aliquots until analysis. CRP level was measured by immunoturbidimetry (Melamies, 1983) using the CRP-Latex ${ }^{\mathrm{TM}}$ (DENKA SEIKEN CO. Tokyo, Japan) and an automatic chemical analyzer, Hitachi $747-100$ (Hitachi CO. Japan). The detection limit of the assay was $<0.1 \mathrm{mg} / \mathrm{l}$. Cytokines were measured by the sandwich enzyme-linked immunosorbent assay systems (Endogen Inc., Woburn, MA, USA). The detection limits were $<3 \mathrm{pg} / \mathrm{ml}$ for $\mathrm{IL}-10,<2 \mathrm{pg} / \mathrm{ml}$ for $\mathrm{IL}-8,<1 \mathrm{~g} / \mathrm{ml}$ for $\mathrm{IL}-1 \beta, \quad<5 \mathrm{pg} / \mathrm{ml}$ for TNF- $\alpha$, and $<0.3 \mathrm{ng} / \mathrm{ml}$ for sICAM-1.

\section{Isolation and activation of monocytes}

For isolation of monocytes, $30 \mathrm{ml}$ of peripheral blood was collected in a heparinized syringe and centrifuged for $5 \mathrm{~min}$ at $800 \mathrm{~g}$ in a tabletop centrifuge. Plasma was collected and stored at $-70^{\circ} \mathrm{C}$. The pelleted blood cells were resuspended in $30 \mathrm{ml}$ of phosphate buffered saline (PBS), overlaid on Histopaque 1077 (Sigma Diagnostics, Inc., St. Luis, MO, USA) and centrifuged at $3000 \mathrm{rpm}$ for $15 \mathrm{~min}$. Cells in the interface were collected and washed twice with PBS and then counted. For the activation with Lipopolysaccharide (LPS), $1-3 \times 10^{7}$ cells were plated in $10 \mathrm{ml}$ of RPMl 1640 medium. The plate was then incubated at $37^{\circ} \mathrm{C}$ for $1 \mathrm{~h}$ to allow monocytes to adhere to the plate surface. Non-adherent cells were then removed by washing the plate twice with a medium. The remaining cells were used for either RNA extraction (for basal level of cytokine mRNA) or activation with $1 \mu \mathrm{g} / \mathrm{ml}$ LPS for $3 \mathrm{~h}$.

\section{Northern Blot analysis}

Total cellular RNA (7-15 $\mu \mathrm{g})$ was electrophoresed in an Agarose gel containing formaldehyde, blotted onto a hybridization transfer membrane (Du Pont-NEN, Boston, MA, USA), then hybridized with cytokine specific DNA probes. Probes were all derived from cDNA clones purchased from American Type Culture Collection (Manassas, VA, USA).

\section{Flow cytometric analysis}

Flow cytometric analysis of lymphoid cells was performed on FACS-Vantage (Becton-Dickinson, Mountain View, $C A)$. Cell staining for flow cytometric analysis was performed as described previously (Lee, et al., 1994). Briefly, $50 \mu \mathrm{l}$ of whole blood was stained with $50 \mu \mathrm{l}$ of staining solution (PBS containing $0.5 \% \mathrm{BSA}$ and $0.1 \%$ $\mathrm{NaN}_{3}$ ) containing $0.5 \mu \mathrm{g}$ anti-HLA-DR-FITC and $0.5 \mu \mathrm{g}$ of anti-CD3-PE for $20 \mathrm{~min}$ on ice (purchased from Pharmingen, San Diego, CA, USA). Fixation and RBClysis were done using Cal-Lysis solution as described by the manufacturer (CALTAC lab, Burlingame, CA, USA). Stained cells were suspended on 2\% PFA in PBS and kept in $4^{\circ} \mathrm{C}$ refrigerator until the time of analysis. Upon flow cytometric analysis, data on 30,000 cells were collected and HLA-DR expression was analyzed in CD3+ positive cells.

\section{Statistical analysis}

Statistical analysis for the comparison of cytokine mRNA and HLA-DR level was done using a non-parametic students $T$ test and the correlation between basal cytokine mRNA levels was analyzed using Spearmans correlation analysis. Chi-square test was used for the analysis of patients with higher than normal level of 
Table 1. Cytokine mRNA levels in monocytes isolated from angina patients and normal subjects.

\begin{tabular}{|c|c|c|c|}
\hline \multirow{3}{*}{$\mathrm{n}$} & \multirow{2}{*}{ Normal } & Unstable & Stable \\
\hline & & Angina & Angina \\
\hline & 12 & 12 & 12 \\
\hline \multicolumn{4}{|c|}{ Basal level } \\
\hline MCP-1 & $1.00 \pm 0.17$ & $7.00 \pm 4.97$ & $3.26 \pm 1.38$ \\
\hline TF & $1.00 \pm 0.24$ & $1.94 \pm 0.37$ & $1.86 \pm 0.43$ \\
\hline IL-8 & $1.00 \pm 0.12$ & $1.09 \pm 0.18$ & $1.53 \pm 0.30$ \\
\hline IL-1 $\beta$ & $1.00 \pm 0.13$ & $1.33 \pm 0.16$ & $1.42 \pm 0.19$ \\
\hline TNF- $\alpha$ & $1.00 \pm 0.21$ & $1.27 \pm 0.20$ & $1.28 \pm 0.23$ \\
\hline TGF- $\beta 1$ & $1.00 \pm 0.12$ & $0.94 \pm 0.07$ & $0.93 \pm 0.07$ \\
\hline \multicolumn{4}{|c|}{ After activation with LPS } \\
\hline MCP-1 & $9.08 \pm 1.79^{\star \star \star}$ & $12.91 \pm 2.78^{*}$ & $12.59 \pm 3.10^{*}$ \\
\hline TF & $11.86 \pm 1.58^{\star \star *}$ & $13.49 \pm 2.23^{\star * *}$ & $12.13 \pm 1.45^{\star \star \star}$ \\
\hline IL-8 & $5.37 \pm 0.55^{\star \star \star}$ & $4.59 \pm 0.54^{\star \star \star}$ & $5.02 \pm 0.50^{\star \star \star}$ \\
\hline IL-1 $\beta$ & $3.07 \pm 0.27^{\star \star \star}$ & $2.77 \pm 0.23^{*}$ & $2.95 \pm 0.18^{* *}$ \\
\hline TNF- $\alpha$ & $8.52 \pm 1.17^{\star * *}$ & $9.44 \pm 1.99^{\star \star \star}$ & $7.22 \pm 0.70^{\star \star \star}$ \\
\hline
\end{tabular}

Values are mean \pm S.E. of the cytokine signal/GAPDH ratio, The values were derived by setting the mean value of normal subjects (before activation) as 1 ${ }^{*} p<0.005,{ }^{* *} p<0.001$, and ${ }^{* * *} p<0.0001$ for the comparison of values before and after LPS stimulation.

cytokine mRNA and re-hospitalization rate of patients with elevated CRP level. A $p$ value below 0.05 was considered as statistically significant for all tests.

\section{Results}

Activation of monocytes with LPS resulted in a statistically significant increase in cytokine mRNA levels in all test groups $(p<0.005$ in all cases) (Table 1$)$. Monocytes isolated from angina groups tended to express higher basal mRNA levels of IL-8, IL-1 $\beta$, MCP- 1 , TNF- $\alpha$, and TF than that of the control group. However, this difference was not statistically significant. The basal levels of cytokine mRNAs were similar between stable and unstable angina patients. The percentages of patients expressing higher than normal levels of cytokine mRNAs were significantly increased: $37.5 \%, 29.2 \%, 33.3 \%$, and $37.5 \%$ for IL-8, IL-1 $\beta$, MCP-1, and TF $(p=0.0143$, $0.0371,0.0233$, and 0.0143 , respectively) (Figure 1). The overall distribution of the basal cytokine mRNA levels was more heterogeneous in angina patients than the control group. The basal levels of MCP-1, IL-8, TF, and IL-1 $\beta$ had significant correlation with each other ( $p<0.01$ in all combinations). In contrast, the basal level of TNF- $\alpha$ and TGF- $\beta 1$ failed to show any correlation with other cytokines tested (Table 2).

Stimulation of monocytes with LPS resulted in slightly higher expression of MCP-1 and TF mRNA in angina patients than in the control group but the difference was not statistically significant between the groups. However,
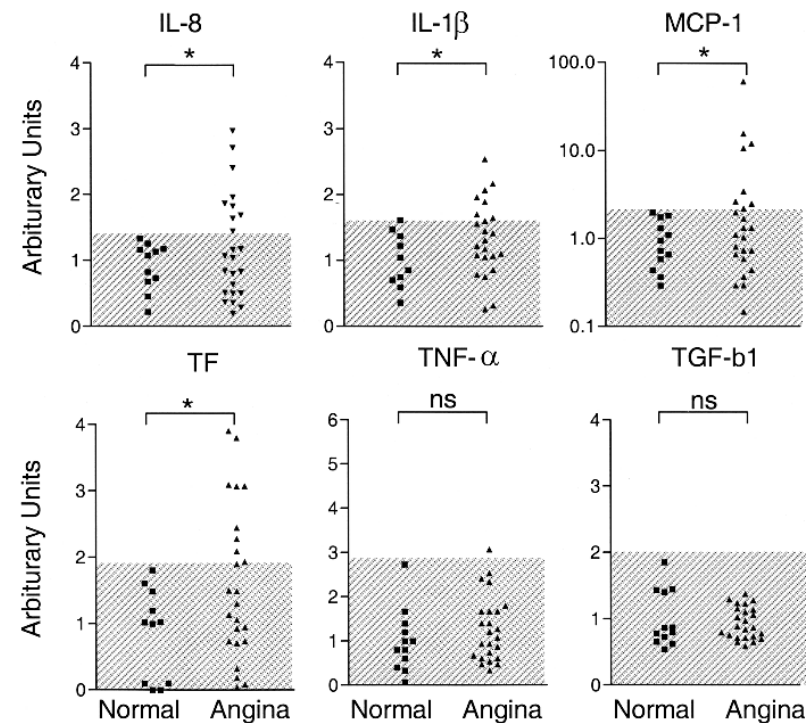

Figure 1. Comparison of basal level of cytokines mRNAs between normal subjects and angina patients. Individual point represent the cytokine/signal ratio. The values were normalized by setting the mean value of normal subjects as 1 . Shaded areas indicate normal range. ${ }^{*} p<0.05$.

Table 2. The correlation among the basal cytokines levels. Calculation was based on Spearman correlation analysis. Numbers represent Spearman correlation coefficient. Numbers in the parenthesis represent $p$ values.

\begin{tabular}{|c|c|c|c|c|c|c|}
\hline \multirow{2}{*}{$\mathrm{n}$} & IL-8 & MCP-1 & TF & IL-1 $\beta$ & TNF- $\alpha$ & TGF- $\beta 1$ \\
\hline & 36 & 36 & 36 & 33 & 36 & 36 \\
\hline IL-8 & - & $\begin{array}{c}0.68634 \\
(<0.0001)\end{array}$ & $\begin{array}{c}0.7119 \\
(<0.0001)\end{array}$ & $\begin{array}{c}0.73188 \\
(<0.0001)\end{array}$ & $\begin{array}{l}0.22457 \\
(0.1879)\end{array}$ & $\begin{array}{l}0.04989 \\
(0.7726)\end{array}$ \\
\hline MCP-1 & & - & $\begin{array}{c}0.4249 \\
(0.0098)\end{array}$ & $\begin{array}{c}0.450177 \\
(0.0086)\end{array}$ & $\begin{array}{l}0.16557 \\
(0.3345)\end{array}$ & $\begin{array}{l}0.21709 \\
(0.2034)\end{array}$ \\
\hline TF & & & - & $\begin{array}{c}0.68140 \\
(<0.0001)\end{array}$ & $\begin{array}{l}0.32768 \\
(0.0511)\end{array}$ & $\begin{array}{l}0.05510 \\
(0.7496)\end{array}$ \\
\hline IL-1 $\beta$ & & & & - & $\begin{array}{l}0.22568 \\
(0.2067)\end{array}$ & $\begin{array}{l}0.34921 \\
(0.0464)\end{array}$ \\
\hline TNF- $\alpha$ & & & & & - & $\begin{array}{c}-0.02578 \\
(0.8813)\end{array}$ \\
\hline TGF- $\beta 1$ & & & & & & - \\
\hline
\end{tabular}

in the expression of MCP-1 mRNA, there was a significant increase following the LPS activation $(p=0.0020)$ (Table 1). Other cytokine levels of angina patients failed to show any statistically significant increase when compared to those of the control group. TGF- $\beta 1$ mRNA level following activation was excluded from the data. LPS induced a high level of TGF- $\beta 1$ expression $1 \mathrm{~h}$ following activation and returned to the near-normal level within 3 hours.

We also tested the activation status of the circulating T-lymphocytes in angina patients. When circulating CD3+ lymphocytes were tested for the HLA-DR+ specific cells, the unstable angina group had a significant increase $(23.8+1.4 \%)$ compared to the control group $(14.3+1.2 \%) \quad(P=0.0004)$ and almost all of the 


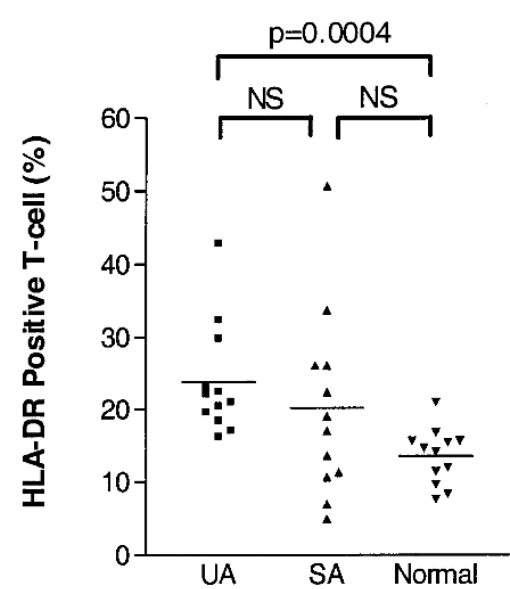

Figure 2. Comparison of the percentage of HLA-DR positive T-cells in patients with unstable angina (UA), stable angina (SA) and normal subjects (N). Expression levels of the markers were analyzed by using flow cytometry. Lines indicate mean values.

unstable angina patients had elevations in HLA-DR+ Tcells compared to the control group. Stable angina patients also showed an increase in the level of HLA$\mathrm{DR}+\mathrm{T}$-cells $(20.2+3.5 \%)(p=0.3124)$ but the number of patients with a significant elevation in the percentage of HLA-DR+ T-cells was relatively small (Figure 2).

We also tested the plasma level of inflammatory markers including CRP, TNF- $\alpha$, IL-8, IL-10, IL-1 1 , and sICAM-1. Plasma levels of CRP were found to be higher in both unstable $(1.63+0.70 \mathrm{mg} / \mathrm{l})$ and stable angina groups $(0.93 \mathrm{mg} / \mathrm{l}+0.31)$ compared to the control group $(0.22+0.08 \mathrm{mg} / \mathrm{l})$. This difference was statistically signifi-cant ( $p=0.028$ and 0.0226 respectively). Furthermore, $83 \%$ of normal subjects (10 out of 12 ), $42 \%$ of the unstable angina (5 out of 12), and $50 \%$ of the stable angina patients (6 out of 12) had normal levels $(<0.3$ $\mathrm{mg} / \mathrm{l})$ of CRP. Since plasma CRP level was reported to be associated with future development of coronary events, we analyzed the association between the observed values and the 6 months follow-up data derived from the patients. As shown in Table 3, the rehospitalization rate in patients with CRP elevation was significantly increased when compared to the patients without CRP elevation (67 vs $0 \%, p=0.0012$ ). Most rehospitalized patients (5 out of 8 cases) received coronary artery bypass grafts due to recurrent angina pain not relieved by usual medications.

Plasma levels of TNF- $\alpha$, IL-8, IL-10, IL-1 $\beta$, and sICAM-1 did not show any correlation with the disease types nor any difference between the control and patient groups (data not shown).

\section{Discussion}

Cytokines such as IL-1 $\beta$, IL- 8 , TNF- $\alpha$, and MCP-1 have
Table 3. Correlation between plasma CRP level and complications in angina patients.

\begin{tabular}{lccl}
\hline $\begin{array}{l}\text { Further events after } \\
\text { hospitalization (6 months) }\end{array}$ & $\begin{array}{c}\text { CRP } \\
<0.3 \mathrm{mg} / \mathrm{ll} \\
\left(\mathrm{n}=10^{\mathrm{b}}\right)\end{array}$ & $\begin{array}{c}\text { CRP } \\
\left(\mathrm{n}=12^{\mathrm{c}}\right)\end{array}$ & \\
\hline Re-hospitalization & 0 & $8(67 \%)$ & 0.0012 \\
- Recurrent angina and CABG & 0 & 5 & 0.0202 \\
- Ischaemic cardiomyopathy & 0 & 1 & $\mathrm{~ns}$ \\
- Recurrent unstable angina & 0 & 1 & $\mathrm{~ns}$ \\
- Myocardial Infarction and death & 0 & 1 & $\mathrm{~ns}$ \\
\hline
\end{tabular}

${ }^{a}$ Coronary artery bypass graft

${ }^{b} 5$ stable angina and 5 unstable angina patients. Follow-up data for 1 stable angina patient were missing.

${ }^{6} 6$ stable angina and 6 unstable angina patients. Follow-up data for 1 unstable angina patient were missing.

${ }^{d} p$ values for the comparison of re-hospitalization rate comparison between patients with and without CRP elevation.

been shown to play important roles in the recruitment of leukocytes in atherosclerosis (Ross, 1993). TF expressed on the surface of activated monocytes and macrophages aggravate the thrombus formation when the plaque ruptures (Brand et al., 1991; Drake et al., 1991; Wilcox, et al., 1989).

Our data indicate that circulating monocytes express higher basal levels of these cytokines in some of the angina patients suggesting that the monocytes in these patients are in activated state. The strong correlation between the basal levels of these cytokines indicates that our observations are not caused by individual variations. In these patients, the activated circulating monocytes express high levels of multiple atherogenic cytokines. Higher expression of TF mRNA in some of the angina patients might indicate that the circulating monocytes in these patients may express higher level of TF and that the enhanced coagulation response may follow in these patients. These factors may contribute in the increased risk of developing acute coronary events in these patients. It would be interesting to find out whether monocytes are activated as a part of the pathogenesis of atherosclerosis or as a result of inflammatory changes associated with the acute coronary syndrome.

Although our study was limited to the Northern analysis of cytokines expressed in the circulating monocytes following LPS activation, it can be correlated with the levels of cytokine in the circulation since the monocytes are the major contributors of these proteins circulation. However, such assumption has to be supported by the experimental data in the futhre.

It is interesting to note that the basal level of TNF- $\alpha$ mRNA was not correlated with other cytokine mRNA levels. The reason may be that TNF- $\alpha$ is an acute phase reactant and barely detectable in the control plasma. The elevated levels of TNF- $\alpha$ mRNA in the activated monocytes suggest possible participation of 
foam cells as well as monocytes in the expression of TNF- $\alpha$ mRNA following activation with atherogenic substances such as oxi-LDL.

The plasma levels of active form of TGF- $\beta 1$ were increased with the occurrence and severity of coronary artery disease (CAD) (Wang et al., 1997). Pro-TGF- $\beta 1$ is synthesized virtually in all cell types and secreted as a latent complex combined with a latency-associated protein. We could not demonstrate any significant differences in the level of pro-TGF- $\beta 1$ mRNA in the circulating monocytes since our analysis measured only the total expression level of pro-TGF- $\beta 1$. It is likely that the total expression level of pro-TGF- $\beta 1$ is similar in monocytes from either the angina patients or the normal control subjects, but the transition of the pro-TGF- $\beta 1$ to active form is more prevalent in angina patients.

In our study, the basal expression levels of inflammatory cytokines of monocytes were increased in $20 \%$ $33 \%$ of the angina patients and difference between the stable angina and unstable angina was not statistically significant. We tested the patients with acute coronary syndrome admitted at the emergency room before or right after the anti-anginal medications were administered. Preliminary data indicated that both monocytes and $T$ cells are activated at high levels with strong statistical significance. This indicates that anti-anginal medications are effective in suppressing the activation of monocytes through some calming effect on the expression of pro-atherogenic cytokines. We are currently testing the monocyte activation status during the course of medical treatment after hospital admission. It is also required to test the activation of monocytes in more specific subsets of angina patients, since even unstable angina can be divided into either acute, active stage or chronic stage.

Among the 24 angina patients participated in our study, 4 unstable and 4 stable angina patients were rehospitalized due to either a minor or a major coronary events within 6 months. Haverkate et al. (Haverkate et al., 1997) reported that the serum level of CRP is a good indicator of future coronary events within two years in both stable and unstable angina patients based upon the data analysis of the serum concentrations of CRP and serum amyloid A protein in stable and unstable angina patients. Analysis of plasma taken from the patients who participated in our study revealed a strong correlation between the elevations in the plasma levels of CRP, not in the plasma levels of other inflammatory cytokines, and the occurrence of minor or major coronary events within 6 months. We also investigated whether the elevation in the level of CRP correlated with the activation of monocytes or T-lymphocytes. Results indicated that neither the cytokine mRNA levels in monocytes nor HLA-DR positive T-cell percentages showed any significant correlation with the plasma CRP levels (data not shown). Further analysis of activation markers of T-lymphocytes and monocytes associated with the plasma CRP level will reveal the significance of CRP elevation in CAD.

\section{Acknowledgments}

This work was supported by the Samsung grant, \#SBRI C98-004 and by the 1998 National R\&D program, MOST, ROK (\#98-N1-02-02-A-05).

\section{References}

Arai, K. I., Lee, F., Miyajima, A., Miyatake, S., Arai, N. and Yokota, T. (1990) Cytokines: coordinators of immune and inflammatory responses. Annu. Rev. Biochem. 59: 783-836

Azar, R. R. and Waters, D. D. (1996) The inflammatory etiology of unstable angina. Am. Heart. J. 132: 1101-6

Bahadori, L., Milder, J., Gold, L. and Botney, M. (1995) Active macrophage-associated TGF-beta co-localizes with type I procollagen gene expression in atherosclerotic human pulmonary arteries. Am. J. Pathol. 146: 1140-9

Barath, P., Fishbein, M. C., Cao, J., Berenson, J., Helfant, R. H. and Forrester, J. S. (1990) Detection and localization of tumor necrosis factor in human atheroma. Am. J. Cardiol. 65: 297-302

Brand, K., Fowler, B. J., Edgington, T. S. and Mackman, N. (1991) Tissue factor mRNA in THP-1 monocytic cells is regulated at both transcriptional and posttranscriptional levels in response to lipopolysaccharide. Mol. Cell. Biol. 11: 4732-8

Clinton, S. K., Underwood, R., Hayes, L., Sherman, M. L., Kufe, D. W. and Libby, P. (1992) Macrophage colonystimulating factor gene expression in vascular cells and in experimental and human atherosclerosis. Am. J. Pathol. 140: 301-16

Cushing, S. D., Berliner, J. A., Valente, A. J., Territo, M. C., Navab, M., Parhami, F., Gerrity, R., Schwartz, C. J. and Fogelman, A. M. (1990) Minimally modified low density lipoprotein induces monocyte chemotactic protein 1 in human endothelial cells and smooth muscle cells. Proc. Natl. Acad. Sci. U. S. A. 87: 5134-8

De Meyer, G. R. and Herman, A. G. (1997) Vascular endothelial dysfunction. Prog. Cardiovasc. Dis. 39: 325-42

Drake, T. A., Hannani, K., Fei, H. H., Lavi, S. and Berliner, J. A. (1991) Minimally oxidized low-density lipoprotein induces tissue factor expression in cultured human endothelial cells. Am. J. Pathol. 138: 601-7

Hansson, G. K., Holm, J. and Jonasson, L. (1989) Detection of activated $T$ lymphocytes in the human atherosclerotic plaque. Am. J. Pathol. 135: 169-75

Haverkate, F., Thompson, S. G., Pyke, S. D., Gallimore, J. R. and Pepys, M. B. (1997) Production of C-reactive protein and risk of coronary events in stable and unstable angina. European Concerted Action on Thrombosis and Disabilities 
Angina Pectoris Study Group [see comments]. Lancet. 349: 462-6

Hiscott, J., Marois, J., Garoufalis, J., D'Addario, M., Roulston, A., Kwan, I., Pepin, N., Lacoste, J., Nguyen, H., Bensi, G. and et al. (1993) Characterization of a functional NF-kappa B site in the human interleukin 1 beta promoter: evidence for a positive autoregulatory loop. Mol. Cell. Biol. 13: 6231-40

Ikeda, U., Takahashi, M. and Shimada, K. (1998) Monocyteendothelial cell interaction in atherogenesis and thrombosis. Clin. Cardiol. 21: 11-4

Lee, W. H., Banan, M., Harriss, J. V., Hwang, I., Woodward, E., Youn, H. J. and Gottlieb, P. D. (1994) Cis-acting DNA elements and cell type-specific nuclear proteins which may play a role in regulation of mouse CD8 alpha (Lyt-2) gene transcription. Int. Immunol. 6: 1307-21

Melamies, L. (1983) Rapid quantification of C-reactive protein by centrifugal analysis. Clin. Chem. 29: 696-7

Meydani, S. N. and Dinarello, C. A. (1993) Influence of dietary fatty acids on cytokine production and its clinical implications. Nutr. Clin. Pract. 8: 65-72

Neri Serneri, G. G., Prisco, D., Martini, F., Gori, A. M., Brunelli, T., Poggesi, L., Rostagno, C., Gensini, G. F. and Abbate, R. (1997) Acute T-cell activation is detectable in unstable angina. Circulation 95: 1806-12

Nikol, S., Isner, J. M., Pickering, J. G., Kearney, M., Leclerc, G. and Weir, L. (1992) Expression of transforming growth factor-beta 1 is increased in human vascular restenosis lesions. J. Clin. Invest. 90: 1582-92

Ridker, P. M., Hennekens, C. H., Roitman-Johnson, B., Stampfer, M. J. and Allen, J. (1998) Plasma concentration of soluble intercellular adhesion molecule 1 and risks of future myocardial infarction in apparently healthy men [see comments]. Lancet 351: 88-92

Rosenfeld, M. E., Yla-Herttuala, S., Lipton, B. A., Ord, V. A., Witztum, J. L. and Steinberg, D. (1992) Macrophage colonystimulating factor mRNA and protein in atherosclerotic lesions of rabbits and humans. Am. J. Pathol. 140: 291-300

Ross, R. (1993) The pathogenesis of atherosclerosis: a perspective for the 1990s. Nature 362: 801-9

Schleef, R. R., Bevilacqua, M. P., Sawdey, M., Gimbrone, M. A., Jr. and Loskutoff, D. J. (1988) Cytokine activation of vascular endothelium. Effects on tissue-type plasminogen activator and type 1 plasminogen activator inhibitor. J. Biol. Chem. 263: 5797-803

Terkeltaub, R., Banka, C. L., Solan, J., Santoro, D., Brand, K. and Curtiss, L. K. (1994) Oxidized LDL induces monocytic cell expression of interleukin-8, a chemokine with T-lymphocyte chemotactic activity. Arterioscler. Thromb. 14: 47-53

Wang, X. L., Liu, S. X. and Wilcken, D. E. (1997) Circulating transforming growth factor beta 1 and coronary artery disease. Cardiovasc. Res. 34: 404-10

Wilcox, J. N., Smith, K. M., Schwartz, S. M. and Gordon, D. (1989) Localization of tissue factor in the normal vessel wall and in the atherosclerotic plaque. Proc. Natl. Acad. Sci. U. S. A. $86: 2839-43$

Yla-Herttuala, S., Lipton, B. A., Rosenfeld, M. E., Sarkioja, T., Yoshimura, T., Leonard, E. J., Witztum, J. L. and Steinberg, D. (1991) Expression of monocyte chemoattractant protein 1 in macrophage-rich areas of human and rabbit atherosclerotic lesions. Proc. Natl. Acad. Sci. U. S. A. 88: 5252-6 